\title{
Predisposition factor Behavior of Early Detection of Cervical Cancer Using Visual Inspection with Acetic Acid Method In Kampung Melayu's Health Center 2018
}

\author{
Melisa Yenti ${ }^{1}$, Caroline Endah Wuryaningsih ${ }^{2}$ \\ \{melisayenti@gmail.com ${ }^{1,}$ caroline2ew@yahoo.com² \\ Faculty of Public Health, Andalas University, Padang, 25163, Indonesia ${ }^{1}$ \\ Universitas Indonesia, Depok, 16424, Indonesia ${ }^{2}$
}

\begin{abstract}
Cervical cancer is cancer with the highest prevalence in Indonesia women. Early detection of cervical cancer using Visual Inspection with Acetic Acid (VIA) method is the government's priority prevention program in controlling cervical cancer, but the coverage of the examination still low. This study aims to identify factors related to early detection behavior of cervical cancer by the VIA method in women aged 30-50 years. A crosssectional study was conducted between December 2017 to June 2018. The subjects of 180 women were selected from using systematic random sampling. Data was collected through interviews using questionnaires and analyzed using the chi-square test. The analysis result showed education $(p=0,026)$, knowledge $(p=0.001)$, and attitude $(p=0.021)$ was associated with early detection of cervical cancer VIA method. Routine socialization and spreading information should be done to increase knowledge and improve women who do early detection of cervical cancer with VIA method.
\end{abstract}

Keywords: early detection, cervical cancer, VIA method, knowledge

\section{Introduction}

Cancer is the second leading cause of death in the world after cardiovascular. According to the International Agency for Research on Cancer (IARC), in 2012, there were 14.1 million new cases of cancer and 8.2 million cancer deaths worldwide. Globally, almost 1 in 6 deaths are caused by cancer. [1]

Of all cancer in the world, poor countries and developing countries account for $57 \%$ of new cases of cancer and account for $65 \%$ of cancer deaths[2]. One of the deadly cancers in women is cervical cancer. Cervical cancer is a malignancy originating from the cervix caused by oncogenic sub-type HPV (Human Papilloma Virus), especially subtypes 16 and 18 [3]. Cervical cancer ranks second in the world, with an incidence rate of 16 per 100,000 women [4].

Cervical cancer is the second-highest prevalence of cancer in women in Indonesia after breast cancer. Meanwhile, the prevalence of cervical cancer in Indonesia is 0.8 per 1000 population[5]. According to the IARC in 2012, the estimated incidence of cervical cancer in Indonesia was 17 per 100,000 women [4]. The number of women with new cervical cancer ranges from $90-100$ cases per 100,000 population, and every year there are 40 thousand cases of cervical cancer[6]. Early detection of cervical cancer is one of the preventive efforts [7]. 
Early detection of cervical cancer can be done with several tests such as pap smear tests, Visual Inspection with Acetic Acid, visual inspection of Lugol iodine, HPV DNA testing, and others [3].

The IVA test is a screening performed by trained health workers by applying 3-5\% diluted acetic acid to the cervix. Then, it will be observed with the naked eye to detect abnormalities. Cervical indications have precancerous lesions if the abnormal area changes color to white (acetowhite) with firm boundaries [3]. According to WHO, coverage of early detection with VIA of at least $80 \%$ for five years will significantly reduce the incidence of cervical cancer [4].

The VIA test is an inexpensive, simple technology with appropriate technology so that this test is a priority program for the government in controlling cervical cancer [4]. The coverage of VIA examinations in Indonesia is still low, from 2007 to 2016, it is still 5.15\% of women aged $30-50$ years who have taken VIA tests [8]. In 2019, the target is $50 \%$ of women aged $30-50$ years [9].

Although early detection of cervical cancer can reduce morbidity and mortality due to cancer, the scope of examination is still low. Various factors were found to influence the behavior of early detection of cervical cancer starting from individual factors, between individuals, and the environment, namely social demographic factors, knowledge and information, attitudes, practices, perceptions, economics, health status, support from husbands, support of friends, support of health workers, interactions with health services and service availability[2][10].

Green explains the behavior formed by predisposing factors, enabling factors, and reinforcing factors. Likewise, with the behavior of early detection of cervical cancer formed by these three factors. Predisposing factors, which facilitate or hinder a person's motivation to behave, include demographics, knowledge, attitudes, beliefs, and values. Knowledge is an important factor in early detection behavior, research conducted in the Maldives by Basu et al., (2014) states that women's knowledge about cervical cancer is still low so there is still little early detection. The study also mentioned that the higher the level of women's education, the better the knowledge[11]. According to research Aweke, Ayanto, \&Ersado (2017) conducted in Ethiopia said that women who have a negative attitude about early detection of cervical cancer do not do early detection. This negative attitude is influenced by women's low knowledge about cervical cancer and early detection[12]. Research conducted by Gianfranco et al., (2015) proves that the level of education is related to the behavior of early detection of cervical cancer [13]. Angelina (2016) also found that occupational status is related to the early detection of cervical cancer VIA method [14].

\section{Method}

Cross-sectional study was conducted in the Kampung Melayu's Health Center 2018 from May to June 2018. The subjects of this study were women aged 30-50 years old. The sample size was calculated using a different proportion hypothesis test formula Lemeshow, which resulted in 161 subjects, and $10 \%$ percent drop rate was considered. The final sample size calculated was 180 . Inclusion criteria include married women mothers aged 30-50 years old. The sampling was done by systematic random sampling. Dependent variables were early detection of cervical cancer using the VIA test, and the dependent variables were level of education, worker, knowledge, and attitude. It was measured by structured interviews using a questionnaire. Data were analyzed by using chi-square. The odds ratio and $95 \%$ confidence interval were calculated. 
P-value $<0.05$ was considered to decide a statistically significant association between the independent and dependent variables.

\section{Result}

Table1. Frequency Distribution of Research Variables

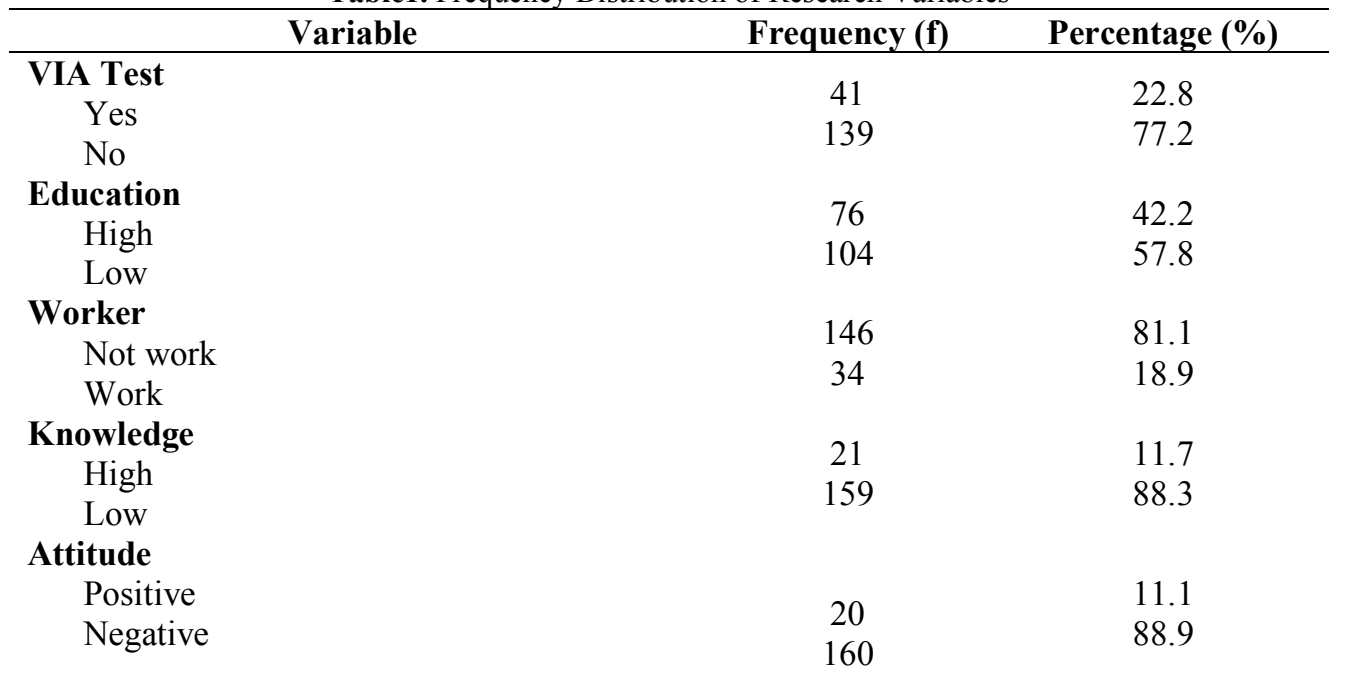

Table 1 shows a small proportion of $22.8 \%$ of mothers who had VIA, $42.2 \%$ had low education, $57.8 \%$ not work, $88.3 \%$ had low knowledge of VIA test, and $88.9 \%$ had a negative attitude to VIA test.

Table 2. Relations of VIA test and Independent Variables

\begin{tabular}{|c|c|c|c|c|c|c|c|c|}
\hline \multirow{3}{*}{ Variable } & \multicolumn{6}{|c|}{ VIA Test } & \multirow{3}{*}{ p-value } & \multirow{3}{*}{$\begin{array}{c}\text { PR } \\
(95 \% \mathrm{CI})\end{array}$} \\
\hline & \multicolumn{2}{|c|}{ Yes } & \multicolumn{2}{|c|}{ No } & \multicolumn{2}{|c|}{ Sum } & & \\
\hline & f & $\%$ & f & $\%$ & $\mathbf{F}$ & $\%$ & & \\
\hline $\begin{array}{c}\text { Education } \\
\text { High } \\
\text { Low }\end{array}$ & $\begin{array}{l}24 \\
17\end{array}$ & $\begin{array}{l}31,6 \\
16.3\end{array}$ & $\begin{array}{l}52 \\
87\end{array}$ & $\begin{array}{l}68.4 \\
83.7\end{array}$ & $\begin{array}{c}76 \\
104\end{array}$ & $\begin{array}{l}100 \\
100\end{array}$ & 0.026 & $\begin{array}{c}2.36 \\
(1.16-4.8)\end{array}$ \\
\hline $\begin{array}{l}\text { Worker } \\
\text { Not work } \\
\text { Work }\end{array}$ & $\begin{array}{c}33 \\
8\end{array}$ & $\begin{array}{l}22.6 \\
23.5\end{array}$ & $\begin{array}{c}113 \\
26\end{array}$ & $\begin{array}{l}77.4 \\
76.5\end{array}$ & $\begin{array}{c}146 \\
34\end{array}$ & $\begin{array}{l}100 \\
100\end{array}$ & 1,000 & $\begin{array}{c}0.949 \\
(0.39-2.29)\end{array}$ \\
\hline $\begin{array}{c}\text { Knowledge } \\
\text { High } \\
\text { Low }\end{array}$ & $\begin{array}{l}13 \\
28\end{array}$ & $\begin{array}{l}61.9 \\
17.6\end{array}$ & $\begin{array}{c}8 \\
131\end{array}$ & $\begin{array}{l}38,1 \\
82.4\end{array}$ & $\begin{array}{c}21 \\
159\end{array}$ & $\begin{array}{l}100 \\
100\end{array}$ & 0,001 & $\begin{array}{c}7.6 \\
(2.88-20.06)\end{array}$ \\
\hline $\begin{array}{l}\text { Attitude } \\
\text { Positive } \\
\text { Negative }\end{array}$ & $\begin{array}{c}9 \\
32\end{array}$ & $\begin{array}{l}45 \\
20\end{array}$ & $\begin{array}{c}11 \\
128\end{array}$ & $\begin{array}{l}55 \\
80\end{array}$ & $\begin{array}{c}20 \\
160\end{array}$ & $\begin{array}{l}100 \\
100\end{array}$ & 0,021 & $\begin{array}{c}3.27 \\
(1.25-8.56)\end{array}$ \\
\hline
\end{tabular}

Table 2 shows education, knowledge, and attitude showed association with VIA test, and work did not show association with VIA test. Analysis results show $31.6 \%$ of mothers with high education did VIA test, and $16.3 \%$ of mothers with low education did VIA test with PR $=2.36$ 
(1.16 - 4.8). $22.6 \%$ of non-working mothers did VIA test, and $23.5 \%$ of working mothers did VIA test with PR $=0.949(0.39-2.29) .61 .9 \%$ of mothers with high knowledge did VIA test, and $17.6 \%$ of mothers with low knowledge did VIA test with PR $=7.6(2.88-20.06) .45 \%$ of mothers with positive attitude did VIA test, and $20 \%$ of mothers with negative attitude did VIA test with $\mathrm{PR}=3.27(1.25-8.56)$

\section{Discussion}

Statistical analysis showed there was a significant relationship between level education with VIA test $P R=2.36$ ( $p=0.026$ ). Women who had high-level education 2.36 times have the opportunity to do VIA test than women who had low-level education. This study is in line with research conducted by Silfia \& Muliati, which states that the level of education is related to the behavior of early detection of cervical cancer. Women who have further education are more likely to conduct VIA examinations than WUS who have basic education [15]. This study is also in line with the study of Gianfranco et al. , which proves that the level of education is related to the behavior of early detection of cervical cancer [13]. Research conducted by Masturoh found that education level has a relationship with the behavior of cervical cancer detection examinations, where WUS with lower knowledge tend not to do early detection[16].

The level of education will affect the exposure of information, insights, and behavior of one's health. The higher the level of education, the better access to information, having good knowledge, and having a good relationship with health workers to seek treatment and obtain health information.

Statistical analysis showed there was a significant relationship between knowledge with VIA test $P R=7.6(p=0.001)$. Women who had a high knowledge of 7.6 times have the opportunity to do VIA tests than women who had low knowledge. It is in line with Omenge et al. finding that the level of knowledge related to the early detection behavior of cervical cancer [17]. Basu et al. reported that knowledge related to early detection behavior of cervical cancer; this study also mentioned that women's knowledge about cervical cancer is still low [11]. Silfia \& Muliati mentioned that knowledge is related to the early detection behavior of cervical cancer, women who have high knowledge about cervical cancer and VIA test have the opportunity to behave early detection of cervical cancer 3.6 times greater than women with low knowledge [15].

Good knowledge of screening tests will increase the possibility of screening. Gu et al. reported that knowledge about cervical cancer and early detection of cervical cancer plays an important role in deciding on tests, increasing knowledge makes WUS motivated to do early detection [18]. Women who have good knowledge are more likely to have VIA examination than WUS with less knowledge [19]. The higher the level of knowledge, the higher the VIA screening behavior [20].

The low level of knowledge is one of the causes of the small number of WUS conducting VIA tests. It is possible because of a lack of understanding and a lack of WUS information about cervical cancer and VIA testing. Lack of understanding because there are still many WUS whose education level is low at $57.8 \%$. The lack of information is due to the limited information obtained by WUS. This limited information can be intervened by conducting communication, information, and education related to cervical cancer and VIA tests. Providing information will 
increase WUS knowledge about cervical cancer and VIA testing. The higher the level of one's knowledge, the ability to make decisions to make early detection of cervical cancer is also better.

Statistical analysis showed there was a significant relationship between attitude with VIA test $\mathrm{PR}=3.27(\mathrm{p}=0.021)$. Women who had a positive attitude 3.27 times have the opportunity to do VIA tests than women who had a negative attitude. This study is in line with other studies conducted by Aweke et al. in Ethiopia also found that there is a correlation between attitude and early cervical cancer detection behavior[12]. Research Masturoh, 2016 shows that there is a significant influence between attitude and WUS behavior in examining cervical cancer with VIA[16]. Research Yuliwati, 2012 Mothers who have a positive attitude are more likely to behave in VIA examination than mothers who have a negative attitude [21]. Research Dewi, et al. show that there is a tendency for WUS to have a good attitude, tend to conduct VIA examination rather than a WUS whose attitude is lacking[22].

Attitude cannot stand by itself. It must relate to other aspects. The attitude variable is not related to the early detection behavior of cervical cancer because most WUS has a low level of knowledge about cervical cancer and VIA tests. WUS feels that it has no possibility of suffering from cervical cancer. This is not true that every woman who has had sexual intercourse has a risk of suffering from cervical cancer. In addition, WUS also feels that the cost of VIA tests is expensive, so they do not want to do VIA tests, even though the VIA test is free, it is covered by health insurance. Counseling about the procedure for examining VIA is important to give to WUS. Many WUS think that the VIA test is scary, sick, and uncomfortable. Providing information regarding the free VIA examination fee that has been borne by BPJS is also very important. Many WUS think that the cost of examining VIA test is expensive, and the examination is not free. This makes WUS don not want to do VIA test.

\section{Conclusion}

Women who had good knowledge tend to do early detection of cervical cancer. It is necessary to increase understanding and eliminate the limitations of information obtained by women. Routine socialization, spreading information through health promotion media, print media, online media, social media, should be done to increase knowledge and improve women who do early detection of cervical cancer with VIA method.

\section{References}

[1] World Health Organization.:Cancer. Taken from http://www.who.int/cancer/en/. (2017)

[2] International Agency for Research on Cancer.: GLOBOCAN 2012: All Cancers Estimated Incidence, Mortality and Prevalence Worldwide in 2012. Taken from http://globocan.iarc.fr/Pages/fact sheets cancer.aspx. (2012)

[3] Kementerian Kesehatan.: Panduan Penatalaksanaan Kanker serviks (Jakarta: Kementerian Kesehatan RI). (2014)

[4] Kementerian Kesehatan.: Buletin Kanker: Situasi Penyakit Kanker. (Jakarta: Kementerian Kesehatan RI). (2015)

[5] Report of Basic Health Research (Jakarta: Badan Penelitian dan Pengembangan Kesehatan RI). (2013) 
[6] Kementerian Kesehatan.: Pedoman Nasional Pelayanan Kedokteran Kanker Serviks (Jakarta: Kementerian Kesehatan RI). (2017)

[7] Kementerian Kesehatan.: Peraturan Menteri Kesehatan RI No 34 tahun 2015 Tentang Penanggulangan Kanker Payudara dan Kanker Leher Rahim (Jakarta: Kementerian Kesehatan RI). (2015)

[8] Kementerian Kesehatan.: Profil Kesehatan Indonesia Tahun 2016 (Jakarta: Kementerian Kesehatan RI). (2016)

[9] Kementerian Kesehatan RI. Panduan Program Nasional Gerakan Pencegahan dan Deteksi Dini Kanker Leher Rahim dan Kanker Payudara. (Jakarta: Kementerian Kesehatan RI). (2015)

[10] Marlow, L. A. et al.: Barriers To Cervical Cancer Screening Among Ethnic Minority Women: A Qualitative Study. Journal of Family Planning and Reproductive Health Care, 41(4). pp.248-254. (2015)

[11] Basu, P. et al.: Knowledge, Attitude and Practices of Women in Maldives Related to the Risk Factors , Prevention and Early Detection of Cervical Cancer. Asian Pacific Journal of Cancer Prevention, 15. pp.6691-6695. (2014)

[12] Aweke, Y. H et al.: Knowledge, Attitude And Practice For Cervical Cancer Prevention And Control Among Women Of Childbearing Age In Hossana Town, Hadiya zone, Southern Ethiopia: Community-based Cross-sectional Study. PLoS ONE, 12(7). pp.1-18. (2017)

[13] Gianfranco, D. et al.: The Impact Of Level Of Education On Adherence To Breast And Cervical Cancer Screening: Evidence From A Systematic Review And Meta-Analysis. Preventive Medicine, Volume 81. (2015)

[14] Angelina, C.: Faktor-Faktor Yang Berhubungan Dengan Deteksi Dini Kanker Leher Rahim Di Kecamatan Gisting Kabupaten Tanggamus Lampung. Jurnal Kesehatan, Volume VII, Nomor 2. pp.228-237. (2016)

[15] Silfia, N. N., \& Muliati, T.: Hubungan Karakteristik, Pengetahuan Dan Sikap Dengan Pemeriksaan Inspeksi Visual Asam Asetat (IVA) Pada Ibu Pasangan Usia Subur di Puskesmas Talise. Jurnal Caring, 1(2). pp. 69-83. (2017)

[16] Masturoh, E.. Faktor - Faktor yang Mempengaruhi Wanita Usia Subur (WUS) dalam Melakukan Deteksi Dini Kanker Serviks Metode Inspeksi Visual Asam Asetat (IVA), 14. (2016)

[17] Omenge, E., et al.: Screening in Western Kenya. PLoS ONE, 11(6). pp.1-13. (2016)

[18] Gu, C., et al.: Understanding The Cervical Screening Behaviour Of Chinese Women: The Role Of Health Care System And Health Professions. Applied Nursing Research, 39. pp.58-64. (2018)

[19] Kurniawati, I.: Pengaruh Pengetahuan, Motivasi Dan Dukungan Suami Terhadap Perilaku Pemeriksaan IVA Pada Kelompok Wanita Usia Subur Di Puskesmas Kedungrejo. Universitas sebelas Maret. (2015)

[20] Sulistiowati, E., \& Sirait, A. M. Pengetahuan Tentang Faktor Risiko, Perilaku Dan Deteksi Dini Kanker Serviks Dengan Inspeksi Visual Asam Asetat (IVA) Pada Wanita Di Kecamatan Bogor Tengah, Kota Bogor. Buletin Penelitian Kesehatan, 42(3). pp.193-202. (2014).

[21] Yuliwati.: Faktor-Faktor Yang Berhubungan Dengan Perilaku Wus Dalam Deteksi Dini Kanker Leher Rahim Metode IVA Di Wilayah Puskesmas Prembun Kabupaten Kebumen Tahun 201. Universitas Indonesia Depok. (2012).

[22] Dewi, N. M. et al.: Hubungan Tingkat Pengetahuan Dan Sikap Wanita Usia Subur (WUS) Dengan Pemeriksaan Inspeksi Visual Asam Asetat (IVA) Di Puskesmas Buleleng I. Jurnal Magister Kedokteran Keluarga, 1(1). pp.57-66. (2013) 